\title{
RETHINKING COMMUNITY IN THE AFTERMATH OF COMMUNITARIANISM: OUTLINES OF A PHENOMENOLOGICAL PATH
}

\author{
REPENSANDO A COMUNIDADE APÓS O COMUNITARISMO: ESBOÇOS DE \\ UM PERCURSO FENOMENOLÓGICO.
}

\author{
ALBERTO PIRNI \\ (Scuola Superiore Sant'Anna / Itália)
}

\begin{abstract}
Three decades after it arose, the contemporary Communitarianism and the questions it raised still appear to be worthy of serious attention. In an attempt to confront this legacy, the first part of the present essay seeks to propose a redefinition of the concept of community. It does so by setting itself two key phenomenological questions, which are both devoted to the concept of sharing. The first question asks how something can be shared amongst multiple beings who are divided by emotional, ethical, religious, linguistic and ethnic differences. The second and no less fundamental question, in turn, asks what people have to share in the first place. The second part of the essay invokes a familiar Kantian distinction in order to sketch out and discuss a proposed 'semantics of sharing'. This semantic model is intended to clarify and enrich the questions surrounding the 'integration of the self', which constitutes one of the most central aspects of the human being's need for sociality.
\end{abstract}

Key-words: community; communitarianism; phenomenological theory; pluralism; modernity; sharing; Kant, Immanuel.

\section{Introduction: what is the (conceptual) future of community?}

This essay seeks to outline a path by which it might be possible to rethink the idea of community in a way that I hope does not immediately lead us into a dead-end. I have embarked on this exercise with the aim of testing the notion of community - and the semantic framework it implies - as a renewed tool for interpreting some of the principal ethical and political challenges of the contemporary age. These challenges are in large part already familiar and, in any case, cannot be enumerated here. For want of a brief summary, they can be described as challenges connected to pluralism, the greatest and, simultaneously, most controversial accomplishment of modernity. Whilst pluralism dovetails with the full and indisputable expression of individual freedom, in today's world it appears increasingly problematic, ever more liable to descend into a radical ethical relativism or alarming political indifferentism. 
In addressing such challenges, the notion of community must make a contribution to the resolution of an essential and universal question, one that involves mankind and that is pondered in all parts of the world: "how can we live together?" We are dealing with a question that presupposes a response that is ethical and political at the same time but which, if confronted in terms of the idea of community, clashes with a series of terminological, conceptual and historical difficulties. The latter two types are above all of an ideological nature: after the fall of the III Reich on the one hand and following the break-up of the USSR on the other the term, community, though differently interpreted but, nonetheless, forever semantically related to either of these two spiritual climates of the past century, appeared to be headed for a destiny of oblivion. This destiny is commensurate with that of the thought-systems and ideologies by which it had been predominantly used for purposes the judgement of which has been entrusted to history (and the history of interpretations, of course).

Nonetheless, at the beginning of the eighties, whilst the first prophetic creaks in the system began to warn of the collapse of the Berlin Wall, beyond the Atlantic Ocean a variegated philosophical and intellectual movement made its first steps. This movement would prove the most important return to thinking about the core problems underlying the concept of community and would come to be known under the label of communitarianism. Communitarianism, whose exponents include, on first approximation, authors of diverse backgrounds and orientations like Alasdair MacIntyre, Michael Sandel, Charles Taylor, Philip Selznick, Robert Bellah, Amitai Etzioni, Roberto Unger and Michael Walzer, ${ }^{1}$ was born as a movement of dissatisfaction with and reaction against the contemporary liberal paradigm characterised by the (in many ways different) ideas of John Rawls, Robert Nozick and Jürgen Habermas. ${ }^{2}$ It sets out to rebalance the (exclusive) attention conferred by the latter group of intellectuals upon individual liberty and the subject of rights and, in doing so, it develops a series of theoretical proposals that are opposed, alternative or complementary to that which it opposes. ${ }^{3}$ These theoretical developments follow two basic trajectories.

Firstly, communitarian scholars began a profound reconsideration of the notion of the self: it was valorised for its possession of ethical and emotional depths which cannot be shed from the individual perspective through which all perceive and act in the world that surrounds us. The liberal doctrines would not have taken such a complex point into account, that is to say they would have unconsciously misunderstood it, considering it substantially irrelevant as far as the 
public dimension of life was concerned. Secondly, communitarians criticised the (merely presumptive) neutrality of justice as conceived and upheld by liberals and the primacy that they give it, which fails to consider the fact that every idea of justice presupposes a certain idea of good that is shared within the community and that informs and defines its contours. The latter objection, in a nutshell, derives from the conviction according to which one defines what is right/wrong on the basis of a shared and preliminary (however latent or unexpressed) definition of what is good to do or avoid in an overall sense.

Though altogether it represents one of the most significant contributions to contemporary debate, communitarianism has nonetheless been variously criticised for bringing into being through its numerous exponents - an ambiguous and in many respects generic concept of community, which has never been defined in a rigorous way, and, precisely for this, has been applied with a certain nonchalance to describe social groups that vary greatly in terms of size and nature: from the family to the village, from the ethnic group to the nation, from voluntary association with the State to unions of States. ${ }^{4}$

To assume a more even-headed assessment of things, detached from the frequent polemical excesses that are typical of the first phase of any debate, the results of the communitarians' reflections today appear to suggest (at least) two further directions of thought. Firstly, in a confirmation of the fact that communitarianism gave voice - even if in perhaps inadequate terms - to a constant human need, we are being warned with some force and from many quarters of the emergence of a yearning for community, to echo the celebrated expression of Zygmunt Bauman, ${ }^{5}$ which begs to be analysed, understood and - within the limits that are granted to us - satisfied. This is a requirement which goes hand in hand with an indefectible need for security which in its turn transforms into a need to take up, reformulate and respond to the question of identity, even though this occurs within the society of risk ${ }^{6}$ to which we are condemned.

Secondly, one can perceive the necessity of taking such needs into account, i.e. of treating them as part of the ethos of Western modernity: the liberal tradition, and within this context of trying to rethink the discourse about community in a new way, seeking to redefine its outlines and limits. In other terms, there is a need to undertake a project of reinterpretation that would have to face the difficulties involved, on the one hand, in finding new meanings better adapted to our times and, on the other, of identifying a correlative objective, something already in existence 
that could/should exist for what otherwise might be in risk of remaining a mere flatus vocis or a sterile rhetorical exercise. Whilst keeping the first point in view, it is on the latter one that the present article intends to focus.

\section{An inevitable point of departure}

To try and find corroboration of the need to rethink and, in a sense, to reshape the concept of community, it appears germane to start out from that which is and must remain its centre and subject: man, though not considered as a being that is in and for himself complete and selfsufficient in his own individuality, but rather as a being that is fundamentally open towards those who are different from himself and that is indeed formed thanks to its constant relationality with that which is not only phenomenologically external but also ethically alien to it.

To give substance to this assumption, I would like to begin with a reference to what Kant calls the transcendental aesthetic in his Critique of Pure Reason which he defines as "a science of all principles of a priori sensibility". ${ }^{7}$ For the purposes of this article, we can carry out a simplification of the Kantian discourse and simply consider the transcendental aesthetic as the discipline which scrutinises the basic ways by which external objects enter the process through which the subject, namely the "being that is gifted with reason", gains knowledge. In other words, it concerns the study of how the knowing subject comes into contact with what to him is the external world. As is known, Kant identifies "two pure forms of sensible intuition", ${ }^{8}$ that is two essential modalities through which all our external senses, our sensibility to what surrounds us, operate: space and time. These are the two fundamental directions that govern our being in the world and through which every other being, be it a person or a thing, comes into our field of perception and thus, of experience; we experience and, therefore, know something or somebody only insofar as we manage to locate them in a temporal and spatial dimension.

And so the attempt to shift these fundamental modalities, that is to understand them in a way that is closer to the grammar of meanings, which is imposed on us by the contemporary world, brings us closer to a sensation of dilation on the one hand and compression on the other in a way that is almost paradoxical.

Above all, the space available to man - available that is to the single individual - has decisively widened and dilated. Beyond any simplistic exaltation of the "magnificent and 
progressive destinies" of our time, it is undoubtedly the case that the space in which perception and individual action can extend has been decisively amplified also, but not only, thanks to technological development and modalities that it would be pleonastic to mention here. At the same time, this space has also been, so to speak, deformed and compressed in that it has become a genuine possibility to bring even very distant physical spaces closer together and to be able to validate our own vocal, visual and physical presence in them. Be it via the videoconference or the transoceanic commute, virtual communities or the mobile phone (to give just the best known examples), "the age of access" and of permanent contactability has reached its undoubted maturity. ${ }^{9}$

A substantially analogous situation is also true for the perception of time. "At the same time" and "real time" have become the new buzzwords in communications and have also come to characterise expectations of action and reaction in respect of any phenomenon. Even time has dilated in the sense that, thanks to globalisation, it has become easier and above all more commonplace to think (not just in terms of the economy) that other men and women are right now living in a different time or a different moment of the day. Nonetheless, even this has been compressed: it is a normal thing to be present - simultaneously or almost so - in more than one context, or to find oneself doing more things together at once. The latter experience is, of course, trivially quotidian but from an analytical point of view it is no more than the replication at the micro level of that which occurs at the macro-social one and which is extensively borne out by the work schedules of heads of state and government.

Indeed, one might object that by no means does all this pertain to all men and women; there exist very wide strata of people who certainly live in communities and yet who do not take part in videoconferences, do not travel by air, do not use a mobile phone and would not even know how to switch on a PC. Nonetheless, the scenario that has just been depicted is becoming ever less a game played by the few - rather, those who really shun these developments constitute a considerable silent minority that is getting ready to become part of the majority that already directs - and will only do so to a greater extent - not just the market but also the public policies of numerous states. However one might want to view it, there is a clear trend which the world, and not just the Western one, is heading towards and for which it is currently impossible to envisage a change of course or a signal of discontinuity. 
One might believe that a consideration of this subject is the price that a philosophical understanding of the present has to pay to other disciplines emerging in the busy forge of the social sciences in order to thus attempt an approach, with its own point of view enriched by a comparison with disciplines whose otherness is merely deceptive, to the thematic core of our social present. Given the objective that this essay set itself at its beginning, it would, therefore, be difficult not to consider these further methods for structuring community which, if on the one hand representing an undoubted enlargement of the possibilities for conceiving a variously limited association of humans who act and interact, on the other suggest a feeling, difficult to suppress, that the links created and maintained in this way are artificial and superficial. The latter sensation cannot but induce a sort of scepticism with regards to the re-emergence and current profundity of the notion of community, that is in terms of how much the above-described scenario may represent a realistic range of possibilities for rethinking community today.

On the other hand, sketching out the aforementioned range of possibilities implies not just an understanding of community as a dynamic of sharing amongst similar people, by which I intend an association of culturally and ethnically affiliated people, but rather - notwithstanding an awareness of the fact that this ethnicist conception has been one of the principal ways of imagining community - an emerging understanding of community as a dynamic of sharing amongst dissimilar people.

To paraphrase Isaiah Berlin's paradigmatic distinction between "the liberty of the ancients" and "the liberty of the moderns", ${ }^{10}$ one could contend, in fact, that such an image of the community as one based on similarity, that is as an organic reality of communication and action within the confines of a shared and indisputable moral code, constitutes the community of the ancients. $^{11}$

Besides this model there also exists one that might be termed the community of the moderns, namely a community that is expressed and established in the form of a contract and conceived in a way that is known as the social contract. In order to bypass the well-known dichotomy of community and society that was paradigmatically put forward by Ferdinand Tönnies, ${ }^{12}$ this is a community that borders with and is as a result coextensive with society, understood in turn as an association of men and women who live on the same territory and organise their relations on the basis of a defined and politically shared set of juridical norms. ${ }^{13}$ To follow in the wake of Berlin, it appears necessary today to begin thinking in terms of a post- 
modern community, that is an association of people who, whilst preserving the juridical regulation of human relations and, therefore, also the modern rendering of community, are linked to each other in various ways and yet, at the same time, laidback, connected but free, permanently within reach and yet unbound by responsibility.

This indubitably is one of the traits which must characterise a modern understanding of community, which finds itself faced with the radical development of its twofold destiny: alongside a local conception of community as one that is the result of the physical coexistence of its subjects, a meta-local community is arising and constantly gaining in importance. This type of community tends to lighten or reduce the merely physical dimension of human relationships and to expand that which might be called their non-material dimension. This fact brings up a further characteristic which connotes the participation of the individual in the post-modern community: whilst in antiquity the individual participated and was intensely connected to a single community to the point of having an almost exclusive relationship with it, the individual nowadays - in accordance with the tendency towards progressive liberation that has traversed the whole of modernity - neither can nor typically wants to be the member of a single community, but rather finds himself part of many and thus forced with varying degrees of awareness to participate in all of these with less intensity and constancy.

In this overall landscape it is necessary to reconsider a further aspect that fully belongs to the semantic and conceptual world of the community. To say "community" is often implicitly tantamount to saying "sharing". In other words, we are naturally inclined to think of these two terms as coextensive, namely to think that subjects who are ready to define themselves as united to others by ties of community ipso facto share with them every opinion, value, way of acting etc. Such a presupposition has lain and still lies at the heart of many objections and precautions against use of the term 'community'. I obviously have no intention of asserting here that community does not correspond to the idea of a space shared by many subjects which is (at least partially) formed through common meanings and shared value interpretations; rather, I would like to suggest that, even if it is true that it could not exist without such a shared horizon, this space cannot, nevertheless, be reduced exclusively to this.

Within the space that is the community there exists a further space, occupied by every subject, which is infinitely divisible and in possession of asymptotic extremes: the subject's complete identification with and complete estrangement from every other one. ${ }^{14}$ Shortly 
speaking, the definition of one's own position, namely of one's distance from one pole or the other, is something that is asked of the individual and that neither can nor should be asked as an entry pass by this or that community.

In today's world, this perspective is rendered even more resonant and meaningful - it is enough to think of the vast number of persons with whom we come into contact daily for the most variegated of reasons. Compared to the past, it is possible to note a greatly increased number of interpersonal contacts, and a correspondingly greater capacity for comparison and exchange of opinions and responses with reference to the most common ethical questions. This is, obviously, one of the principal consequences of the technologically advanced mass society which, nonetheless, implies a clarification and, at the same time, narrowing of the meaning of sharing. Nowadays, the notion of sharing refers ever more to the idea of putting out, rendering explicit, that is moving something into the public sphere - by which I simply mean everything that is external to the self ${ }^{15}$ - and refers ever less directly to the reaching of an agreement on what it is that one made explicit or placed under common ownership, on what it is that fills the public space. Sharing, in short, means ever more to externalise and ever less to approve. Moreover, approval is becoming characterised nowadays solely by a common result, having abandoned - or at least strongly reshaped - a common point of departure, which can clearly be found in the community of the ancients and, though with some limitations, in the community of the moderns.

\section{Dynamics of sharing}

The outlook that has been offered so far has helped to amplify and widen one of the questions immediately connected to the debate on community, namely the question of how to share something between multiple beings endowed not only with reason but also different emotional, ethical, religious, linguistic and - last but not least - ethnic characteristics. In short, we are talking about the problem of finding a method to position ourselves, stay and act in a common space inhabited by others as well as us. However, there is a second no less fundamental question that has yet be addressed, namely that which regards what is to be shared and the possible contents of such sharing.

Faced with this question, it might prove beneficial to make another reference to Kant and, in particular, to a terminological distinction, typically attributed to $17^{\text {th }}$ and $18^{\text {th }}$ Century 
Scholasticism and most notably to Pufendord and Thomasius but which was developed by Kant into such a form as would remain paradigmatic. I am referring to the distinction between perfect duties and imperfect duties that was alluded to in his Groundwork of the Metaphysics of Morals (1785) and then taken up again in the later Metaphysics of Morals (1797). To give an extreme summary, whilst the "perfect duty" is "one that admits no exception in favor of inclination", "the "imperfect duty" conversely is one that could contemplate the possibility of an exception.

Bearing this distinction in mind, we could in our turn propose a further one, implicit in the very question of what is to be shared. Amongst perfect duties, it is thus possible to identify a question about what we have to share and another one about what we don't have to share. At the same time, as a complement to this, one will have to consider a question about what we can share and, therefore, also one about what we cannot share.

Certain variations, but also certain aspects of conformity can be found between this preliminary division and that which was expounded by Kant. Above all, it can be noted that both questions are put in both their positive and negative versions and this conforms to the Kantian model, which envisages limiting [einschränkend] duties and widening [erweiternd] duties, that is "duties of omission (sustine et abstine)" and "duties of commission (viribus concessis utere)". ${ }^{17}$

Secondly, though including both in the Metaphysical first principles of the doctrine of Virtue, namely the second part of the Metaphysics of Morals, which follows that devoted to the Metaphysical first principles of the doctrine of Right, one has to remember that "perfect duties" refer back to what Kant termed a "narrow obligation", typical of Right, namely absolute and unconditional, whereas "imperfect duties" are based on a "wide obligation", in the sense that they leave "a playroom (latitudo) for free choice in following (complying with) the law, that is, that the law cannot specify precisely in what way one is to act and how much one is to do by the action for an end that is also a duty" ${ }^{18}$ This does not, however, mean that "imperfect duty" implicitly allows for its own non-fulfilment - it remains, after all, a "duty". Indeed, it only allows one "to limit one maxim of duty by another (e.g., the love of one's neighbour in general by love of one's parents)". ${ }^{19}$ In my adapted version of Kant's dichotomy, this clarification has been consigned to the background but I have sought to reproduce its meaning by employing verbs of obligation and possibility.

Finally, I have so far withheld from referencing a further distinction made by Kant in the same texts in which he distinguishes between "perfect duties" and "imperfect duties". This 
distinction overlaps with the preceding one: both types of duty indeed have to be conceived as part of a further dichotomy - "to oneself" and "to others", which results in an overall four-way division of duties. As I hope is clear in view of this, by seeking to base a reconsideration of this division on the concept of sharing, which by its very nature implies the opening up of the individual towards others, the stress of my paradigm remains on the self, on the single individual who - as will be remembered from the previous paragraph - must find the right equilibrium between the two opposed polarities of complete identification and complete estrangement with regards to the self's relationship with the other.

Considered as a whole, the dynamic of sharing that has been suggested here implies a serious and demanding exercise in tolerance, which is imposed by the insurmountable diversity that we encounter daily. In the face of this, the question about what is to be shared which then opens up and multiplies into four further questions is subject to a sort of globalised, postmodern categorical imperative which echoes the commitment to learn about what is different that was so masterfully exemplified by Clifford Geertz; it could be summed up as the need to "learn to understand what we cannot accept" ${ }^{20}$ We have to set out from a position of universal tolerance which implies, above all, the suspension and preliminary sidelining of every one of our value judgements in respect of the other and the undertaking of a dynamic of relationality and listening. The aforementioned quadrichotomy between having to/not having to and being able to/not being able to share what the other expresses and embodies starts from here. The consequent acceptance (or less than this) is linked to the peculiar definition of the concept of sharing that was offered above but must in addition remain aware of a further semantic requirement. If sharing means above all placing under common ownership, "putting into the public space" more than "agreeing", one should not forget the possibility of interpreting this verb as meaning "the division of things between more than one person without resulting in a diminution of what is being divided in any way"; not a subdivision, therefore, but rather distribution with conservation with the aim of acting in conformity with what was placed under common ownership, but without resigning one's individual responsibility for what one does.

At this point it is possible to trace the outlines of what I would like to call the semantics of sharing, whose fundamental traits can only be understood in the light of the quadruple distinction. Of course, this is a purely phenomenological attempt that does not claim nor seek in any way to define the content of the solution to the question about what is to be shared; and that 
is anchored so comprehensively in the liberal ethos, but which not for this renounces the idea of putting forward a framework in which to understand and occasionally seek to answer it. Yet again, the point of departure and the centre of this phenomenology is the self, that is the identity of the subject, conceived as something that constitutes itself in a dialogic way, and articulated within a constantly re-emerging dynamic between acceptance and rejection of what is different from the self. ${ }^{21}$

Within this perspective, then, as far as so-called "imperfect duties" are concerned, we cannot share that which is different from us and which claims to engage the centre of our self, whilst - on the other hand - we can share that which is different from us and which attempts to integrate the periphery of our self. At the same time, in terms of "perfect duties", we do not have to share all that offends the dignity (and the integrity) of man whilst, conversely, we must share that which promotes it.

This schematic partition, of course, needs to be accompanied by certain clarifications. Above all, it can be noted that both of the positive verbalisations of the "duty to share" are constructed as the same forms of the integration of the self with the spiritual enrichment of the single subject as its aim. They, therefore, tend through their very nature to trigger a productive and extensive dynamic towards the self, that stimulates dialogue and comparisons with the other, starting out from the conservation of that which has been acquired and articulated on the level of one's own identity. On the contrary, but in equal measure, both of the negative verbalisations attempt to block the same forms of distorting the self which, rather than engaging and stimulating its dialogic component, aim to supplant and annihilate what we are and what we have become.

Nonetheless, it is the entire dimension of "perfect duties" that is most problematic. On the one hand, "having to share" all that promotes the idea of human dignity means above all arranging for dialogue with the multiple and different ways by which to maintain the human on a cultural basis. In addition, the absoluteness and unconditional nature of that commandment clashes with the content of the idea behind it, which in its turn is subject to a constant dialectic of redefinitions starting from an irreducible conflict of (self-)interpretations of what man is and ought to be, which grows under a political, ethical and not least juridical guise. The concept of the dignity of man, which ought to constitute the cornerstone and indisputable normative criterion on the basis of which every (ethical, political, juridical) proposal linked to its promotion is approved or disavowed, finds itself instead subject to constant efforts to erode it and is, therefore, 
forced into a repeated hermeneutics of redefinitions in dialogue and, not infrequently, in conflict with a binary problematic polarity: scientific development on the one hand and cultural difference on the other.

It is not possible here to give this subject the attention it might deserve. Nonetheless, one has to take note of a further characteristic and, simultaneously, a limit to the reformulation of the Kantian distinction. Whilst in Kant's eyes "perfect duties" are those that are valid always and in every place, absolutely and unconditionally, the obligation to share which (in its perfect expression) I have tried to link to the concept of dignity now turns out to be relative and conditioned by agreements between subjects that are from time to time reached - via discussion on the meaning of that concept, and this in preparation to the fact that more subjects can talk in the community. To return to a known dichotomy of Geertz's that was developed by Walzer, it is as if there existed a thin meaning of dignity which each of us possesses and understands at an intuitive level. As soon as one seeks to make it explicit to ourselves and to others, however, it has to take on a form that reflects the depth of its meaning, that is expressed in keeping with the values that belong to each of us and which to the other, our interlocutor, may appear convincing but also strange, incomprehensible and even hostile.

Here begins and lies the most radical challenge for ethics and politics which cannot and must not be restricted merely to those in authority but has to involve each of us in our daily lives and actions. And this is no other than the challenge of coexistence which I referred to in the opening: how can we live together, with each dwelling in his own state of difference, and furthermore what does it mean to live together? The attempt to answer these questions - like that which has been put forward in this article - reproduces on a more general scale the circumstances that are linked to the concept of dignity and makes us think that maybe we need little intuition but definitely more willingness to share. Community and living together in today's world constitutes ever less of a necessity and assumes ever more clearly the dimensions of a choice: it remains a task for all of us to interpret this choice as one either in favour of difference or else, indifference. 


\section{Notes}

${ }^{1}$ With the sole purpose of offering an introduction to communitarian scholarship, I suggest here just a relevant essay of each of the aforementioned authors: A. MacIntyre, After Virtue, Duckworth, London 1981 (later: University of Notre Dame Press, Notre-Dame (Ind.) 1984); M. Sandel, Liberalism and the Limits of Justice, Cambridge University Press, Cambridge (Mass.) 1982; Ch. Taylor, Sources of the Self. The Making of the Modern Identity, Harvard University Press, Cambridge (Mass.) 1989; Ph. Selznick, The Moral Commonwealth. Social Theory and the Promise of Community, University of California Press, Berkeley 1992; R. Bellah (ed.), The Good Society, Knopf, New York 1991; A. Etzioni, The Spirit of Community. Rights, Responsibilities, and the Communitarian Agenda, Crown, New York 1993 (later: Simon \& Schuster, New York 1994); R.M. Unger, Knowledge \& Politics, Free Press - Mc Millan, New York - London 1975; M. Walzer, The Communitarian Critique of Liberalism, in «Political Theory», 18 (1990), n. 1, pp. 6-23.

${ }^{2}$ With the same purpose as in the previous footnote, I here cite the following volumes: J. Rawls, A Theory of Justice, Harvard University Press, Cambridge (Mass.) 1971; R. Nozick, Anarchy, State, and Utopia, Blackwell, Oxford 1974; J. Habermas, Theorie des kommunikativen Handelns, Suhrkamp, Frankfurt a.M. 1981, 2 vol.

${ }^{3}$ A broad overview of such a debate, pictured also through the contributions of most of its protagonists, is offered firstly by M.J. Sandel (ed.), Liberalism and Its Critics, London, Blackwell 1984; S. Mulhall - A. Swift, Liberals and Communitarians, Oxford, Blackwell 1992; A. Ferrara (ed.), Comunitarismo e liberalismo, Editori Riuniti, Roma $1992\left(2002^{2}\right)$.

${ }^{4}$ On this point see at least: W. Kymlicka, Liberalism, Community and Culture, Clarendon Press, Oxford 1989, 1991²; Id., Contemporary Political Philosophy. An Introduction, Clarendon Press, Oxford 1990; S. Veca, Filosofia politica, Laterza, Roma-Bari 1998, 2002²; V. Pazé, Il concetto di comunità nella filosofia politica contemporanea, pref. di M. Bovero, Laterza, Roma-Bari 2002; Id., Il comunitarismo, Laterza, Roma-Bari 2004. Moreover, we are here referring to a debate far from over. Within a number of studies, let me mention here at least the following: M. Daly (ed.), Communitarianism: A New Public Ethics, Wadsworth, Belmont (Ca.), 1994; E.A. Christodoulidis (ed.), Communitarianism and Citizenship, Aldershot, Ashgate 1998; H.B. Tam, Communitarianism. A New Agenda for Politics and Citizenship, New York University Press, New York 1998; R. Soriano, Interculturalismo: entre liberalismo y comunitarismo, Almuzara, Cordoba 2004; C. Preve, Elogio del comunitarismo, Controcorrente, Napoli 2006; P. Block, Community. The Structure of Belonging, Berrett-Koehler Publishing, San Francisco 2008; M. Olssen, Liberalism, Neoliberalism, Social Democracy: Thin Communitarian Perspectives on Political Philosophy and Education, Routledge, New York - London 2008; W.E. Hudson, The Libertarian Illusion: Ideology, Public Policy, and the Assault on the Common Good, CQ Press, Washington DC 2008; E. Etzioni, New Common Ground: A New America, A New World, Potomac, Washington DC 2009; A. Vered, R. Nigel, Community, Cosmopolitanism and the Problem of Human Commonality, Pluto Press, London 2012.

${ }^{5}$ Z. Bauman, Community. Seeking Safety in an Insecure World, Polity Press, Oxford 2000.

${ }^{6}$ The reference here is to the celebrated study of U. Beck, Risikogesellschaft. Auf dem Weg in eine andere Moderne, Suhrkamp, Frankfurt a.M. 1986.

${ }^{7}$ I. Kant, Kritik der reinen Vernunft, 2. Auflage (1787), in Akademie-Ausgabe: Kant's gesammelte Schriften, hrsg. von der Preußischen (Deutschen) Akademie der Wissenschaften, Reimer (de Gruyter), Berlin 1900 ss., Bd. III, B 35 [Critique of Pure Reason, transl. and ed. by P. Guyer and A. Wood, Cambridge University Press, Cambridge 1998, p. 156].

${ }^{8}$ Ivi, B 36 [157].

${ }^{9}$ The reference is taken from the famous work of J. Rifkin, The Age of Access. How the Shift from Ownership to Access is Transforming Capitalism, Penguin books, London 2000. One useful way of furthering this line of reasoning seems to have been laid out by Marc Augé in his conception of the non-place, which he uses to denote all those spatial constructions typical of advanced urban modernity (such as the subway and supermarkets) that serve the rapid transit of people and things but are substantially de-essentialised, unable to leave any trace on the memory; these spaces are constantly crossed by myriads of people and yet inhabited by none. Once again one encounters here

ethic@-Florianópolis v. 12, n. 1,p. 1 -14, Jun. 2013. 
a stereotypical case of the dialectic of dilation and compression which I referred to above. For further reading see M. Augé, Non-lieux. Introduction à une antropologie de la surmodernité, Seuil, Paris 1992. An interesting nexus between new forms of community and what the authors call «cosmopolitan anthropology» (in similarity to what we have just proposed) is presented by A. Vered, R. Nigel, Community, Cosmopolitanism and the Problem of Human Commonality, spec. Part I e II.

${ }^{10}$ I. Berlin, "Two Concepts of Liberty", Clarendon Press, Oxford 1958, subsequently reprinted in Four Essays on Liberty, Oxford University Press, Oxford 1969, pp. 118-172.

${ }^{11}$ Broadly speaking, this is the argument made by A. MacIntyre in After Virtue.

${ }^{12}$ F. Tönnies, Gemeinschaft und Gesellschaft, Reislad, Liepzig 1887 (later: Curtius, Berlin 1912, 1926 ; later still: Buske, Darmstadt 1935) [Community and Society, trans. and ed. by C.P. Loomis East Lansing, Michigan State University Press, East Lansing 1957; later: with a new Intr. by J. Samples, New York, Dover 2002].

${ }^{13}$ For a detailed discussion on this topic see F. Fistetti, Comunità, il Mulino, Bologna 2003, spec. pp. 135-140.

14 I have developed a different version of this argument, presenting "complete integration" and "complete misunderstanding" as the two asymptotic extremes of this spatiality in A. Pirni, Il prezzo dell'identità: fra integrazione e misconoscimento, in «Cosmopolis», I (2006), n. 1, pp. 205-212 (accessible at www.cosmopolisonline.it/pirni.htm).

${ }^{15}$ I have approached the subject more at length in A. Pirni, Filosofia pratica e sfera pubblica: percorsi a confronto, Diabasis, Reggio Emilia 2005.

${ }^{16}$ I. Kant, Grundlegung zur Metaphysik der Sitten, in Akademie-Ausgabe: Kant's gesammelte Schriften, Bd. IV, p. 421, Anm. [Groundwork of the Metaphysics of Morals, transl. and ed. by M. Gregor, Intr. By C. Korsgaard, Cambridge University Press, Cambridge 1998, 2010 ${ }^{16}$, p. 31, n.].

${ }^{17}$ I. Kant, Die Metaphysik der Sitten, in Akademie-Ausgabe: Kant's gesammelte Schriften, Bd. VI, p. 419 [The Metaphysics of Morals, transl. and ed. by M. Gregor, Intr. by R.J. Sullivan, Cambridge University Press, Cambridge $1996,2005^{7}$, p. 174].

${ }^{18}$ Ivi, p. 390 [153].

${ }^{19}$ Ibidem.

${ }^{20}$ Geertz appears to acknowledge the existence of such an imperative when he writes: "Comprehending that which is, in some manner of form, alien to us and likely to remain so, without either smoothing it over with vacant murmurs of common humanity, disarming it with to-each-his-own indifferentism, or dismissing it as charming, lovely even, but inconsequent, is a skill we arduously have to learn, and having learnt it, always very imperfectly, to work continuously to keep alive [...]" (C. Geertz, The Uses of Diversity, in Id., Available Light. Anthropological Reflection on Philosophical Topics, Princeton University Press, Princeton (N.J.) 2000, pp. 68-88, p. 87.

${ }^{21}$ I have addressed some implications of this issue in A. Pirni, Vom Umgekehrten ausgehen: Alterität, Anerkennung und Freiheit, in B. Henry, A. Pirni (Hrsg.), Der asymmetrische Westen. Zur Pragmatik der Koexistenz pluralistischer Gesellschaften, Transcript, Bielefeld 2012, pp. 187-207. 